\title{
Tropical cyclone genesis in the Southern Hemisphere and its relationship with the ENSO
}

\author{
Y. Kuleshov ${ }^{1}$, F. Chane Ming ${ }^{2}$, L. Qi ${ }^{1}$, I. Chouaibou ${ }^{2}$, C. Hoareau ${ }^{2}$, and F. Roux ${ }^{3}$ \\ ${ }^{1}$ National Climate Centre, Australian Bureau of Meteorology, Melbourne, Victoria 3000, Australia \\ ${ }^{2}$ Laboratoire de l'Atmosphère et des Cyclones, UMR CNRS-Météo-France-Université de la Réunion, La Réunion, France \\ ${ }^{3}$ Laboratoire d'Aérologie, Université Paul Sabatier, CNRS, UMR 5560, Toulouse, France
}

Received: 18 September 2008 - Revised: 15 May 2009 - Accepted: 8 June 2009 - Published: 24 June 2009

\begin{abstract}
Tropical cyclogenesis climatology over the South Indian and South Pacific Oceans has been developed using a new tropical cyclone (TC) archive for the Southern Hemisphere, and changes in geographical distribution of areas favourable for TC genesis related to changes in the El Niño-Southern Oscillation (ENSO) phases have been investigated. To explain these changes, large-scale environmental variables which influence TC genesis and development such as sea surface temperatures (SSTs), relative humidity in mid-troposphere, vertical wind shear and lower tropospheric vorticity have been examined. In the South Indian Ocean, reduction of TC genesis in the western part of the basin and its increase in the eastern part as well as displacement of the area favourable for TC genesis further away from the equator during La Niña events compared to El Niño events can be explained by changes in geographical distribution of relative humidity and vorticity across the basin as primary contributors; positive anomalies of SSTs observed during La Niña seasons in the eastern part of the basin additionally contribute to enhanced cyclogenesis near the Western Australia. In the South Pacific Ocean, changes in geographical distribution of relative humidity and vorticity appear to be the key large-scale environmental factors responsible for enhanced TC genesis in the eastern (western) part of the basin as well as for the northeast (southwest) shift of points of cyclogenesis during El Niño (La Niña) events, with vertical wind shear and SSTs as additional contributing large-scale environmental variables.
\end{abstract}

Keywords. Meteorology and atmospheric dynamics (Climatology; Mesoscale meteorology; Tropical meteorology)

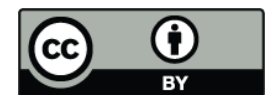

Correspondence to: Y. Kuleshov (y.kuleshov@ bom.gov.au)

\section{Introduction}

Influence of the El Niño-Southern Oscillation (ENSO) phenomenon on tropical cyclone (TC) activity in the various regions of the Southern Hemisphere has been demonstrated in numerous studies (Nicholls, 1984; Hastings, 1990; Evans and Allen, 1992; Basher and Zheng, 1995; Nicholls et al., 1998; Camargo et al., 2007; Kuleshov et al., 2008). It is well known that the ENSO also plays an important role in TC interannual variability in ocean basins of the Northern Hemisphere (e.g. Chu, 2004), although the influence of large-scale environmental factors on TC genesis and development varies for different basins. Gray (1979) formulated six large-scale environmental parameters playing key roles in formation of TCs including the Coriolis parameter, low-level relative vorticity, relative humidity in the mid-troposphere, tropospheric vertical wind shear, ocean thermal energy, and difference in equivalent potential temperature between the surface and $500 \mathrm{hPa}$. Recently, Camargo et al. (2007) used a genesis potential index which is similar to Gray's seasonal genesis index (Gray, 1979) to diagnose ENSO effects on tropical cyclogenesis and concluded that in the basins of the Southern Hemisphere vertical wind shear and mid-tropospheric relative humidity are especially important, vorticity anomalies contribute most significantly in the central Pacific, and thermodynamic variable of the genesis potential index described in terms of potential intensity (Bister and Emanuel, 1998) plays a secondary role. It is well established that vertical wind shear in the Northern Hemisphere, particularly in the North Atlantic, plays a primary role in TC variability related to the ENSO (e.g. Gray, 1984). However, in the Southern Hemisphere it is less obvious because of strong gradients in wind-shear over the regions of cyclogenesis. Also, changes in sea surface temperature (SST) related to changes in ENSO phases are significant in the equatorial and near-equatorial regions of the Indian and Pacific Oceans, and it appears that the

Published by Copernicus Publications on behalf of the European Geosciences Union. 
thermodynamic variable can be in addition one of the important environmental factors contributing to tropical cyclogenesis variability in this region. Thus, it is pertinent to further examine influence of changes in TC surrounding environment on TC genesis. Based on results of earlier studies, large scale environmental factors which influence TC genesis and development such as SST, relative humidity, vertical wind shear and relative vorticity were examined here through the National Center for Environmental Prediction (NCEP) composite re-analysis dataset (Kalnay et al., 1996).

Results of the studies on the relationship between TCs and the ENSO depend on a definition of the ENSO warm (El Niño) and cold (La Niña) phases, which is used to conduct composite analyses and to explain the observed variability. Therefore, it is essential to discuss selection of El Niño and La Niña years in detail. For example, Saunders et al. (2000) used the NINO3.4 sea surface temperature anomalies (SSTA) thresholds of above $+0.3^{\circ} \mathrm{C}$ (below $-0.3^{\circ} \mathrm{C}$ ) to define El Niño (La Niña) conditions. Camargo et al. (2007) selected $25 \%$ of years with the highest (lowest) NINO3.4 values in a season to define El Niño (La Niña) years with the remaining 50\% years defined as neutral. More often, thresholds of above $+0.5^{\circ} \mathrm{C}$ for $\mathrm{El}$ Niño and below $-0.5^{\circ} \mathrm{C}$ for La Niña conditions are used (Climate Prediction Center web page). Though the ENSO has been a subject to numerous studies over the past decades (Troup, 1965; Chen, 1982; Ropelewski and Jones, 1987; Trenberth, 1997) there is no universal agreement on a definition of the ENSO and its phases so far, resulting in various criteria in the delineation between El Niño and La Niña events.

Recently, Kuleshov et al. (2008) examined several key ENSO indices in order to develop a collective list of historical El Niño and La Niña events. The Southern Oscillation Index (Troup, 1965) and the NINO3.4 SSTA (a threemonth running mean of ERSST.v2 SST anomalies in the NINO3.4 region $\left(5^{\circ} \mathrm{N}-5^{\circ} \mathrm{S}, 120^{\circ} \mathrm{W}-170^{\circ} \mathrm{W}\right)$, based on the 1971-2000 base period) which are the two most commonly used indices in defining the ENSO phases, have been examined. Composite indices such as the Multivariate ENSO Index (MEI) (Wolter, 1987) and the Five Variable (5VAR) ENSO Index [an index based on the first principal component of Darwin and Tahiti mean sea level pressure, and the NINO3, NINO3.4 and NINO4 SST indices which is used by the Australian National Climate Centre internally to define ENSO phases (Kuleshov et al., 2009)] have been also examined. Consequently, a list of TC seasons which are considered as El Niño and La Niña seasons has been developed and recommended for subsequent studies on TC activity in the Southern Hemisphere. As the data in the Southern Hemisphere Tropical Cyclone archive start from 1969/70 TC seasons, in this study the following TC seasons from the whole list prepared by Kuleshov et al. (2008) have been selected as El Niño seasons: 1969/70, 1972/73, 1976/77, 1977/78, 1979/80, 1982/83, 1986/87, 1987/88, 1991/92, 1992/93, $1993 / 94,1994 / 95,1997 / 98,2002 / 03$ and 2004/05, and the following TC seasons have been selected as La Niña seasons: 1970/71, 1973/74, 1974/75, 1975/76, 1988/89, 1998/99 and 1999/2000. In the selected 36 year period, there are more TC seasons which are considered as El Niño seasons than those which are considered as La Niña seasons; it was reported by Trenberth (1997) that El Niño conditions occur approximately $31 \%$ of the time and La Niña conditions $23 \%$.

This study aims to examine the TC genesis climatology over the South Indian Ocean and the South Pacific Ocean and to investigate changes in tropical cyclogenesis in different areas of the Southern Hemisphere in relation to changes of large-scale environmental factors associated with the ENSO phases.

\section{Results of analysis of tropical cyclogenesis}

Data from the TC archive for the Southern Hemisphere which has been prepared at the National Climate Centre, Bureau of Meteorology, Australia (Kuleshov et al., 2008) have been used in this study. In the TC archive for the Southern Hemisphere, the best track TC data from the National Meteorological and Hydrological Services of Australia (Bureau of Meteorology), New Zealand (Meteorological Service of New Zealand) and France (Météo-France) were combined into one homogenous dataset. TC data from 1969/70 to 2005/06 TC seasons have been analysed to develop tropical cyclogenesis climatology. For the Southern Hemisphere, the TC year was considered as the 12 month period from July to June inclusive. Fields of the SST, relative humidity in midtroposphere, vertical wind shear and lower tropospheric vorticity have been obtained from the NCEP re-analysis dataset (Kalnay et al., 1996). In this study, geographical boundaries for the South Indian Ocean basin are defined as south to the equator, west of $135^{\circ} \mathrm{E}$, and for the South Pacific Ocean basin as south to the equator, east of $135^{\circ} \mathrm{E}$.

\subsection{The South Indian Ocean}

\subsubsection{Tropical cyclone genesis}

Spatial distribution of TC genesis over the South Indian Ocean basin during all TC seasons from 1969 to 2006, including El Niño, La Niña and neutral phases of ENSO is presented in Fig. 1. In this study, a cyclogenesis point is defined by locating a point along cyclone track where an estimated TC central pressure attained a threshold of $1000 \mathrm{hPa}$ or lower. In the South Indian Ocean, TC genesis is observed over the whole range of longitudes of the basin. The maximum occurrence is located in the area around $\left[5-15^{\circ} \mathrm{S}, 60-130^{\circ} \mathrm{E}\right]$. In the area between African coast and $60^{\circ} \mathrm{E}$, there is a noticeable displacement of the points of TC genesis southwards to $10-25^{\circ} \mathrm{S}$.

Analysis of composite cyclogenesis anomalies demonstrates that during El Niño episodes (Fig. 2a) TC genesis is above climatology in the western part of the basin (west 


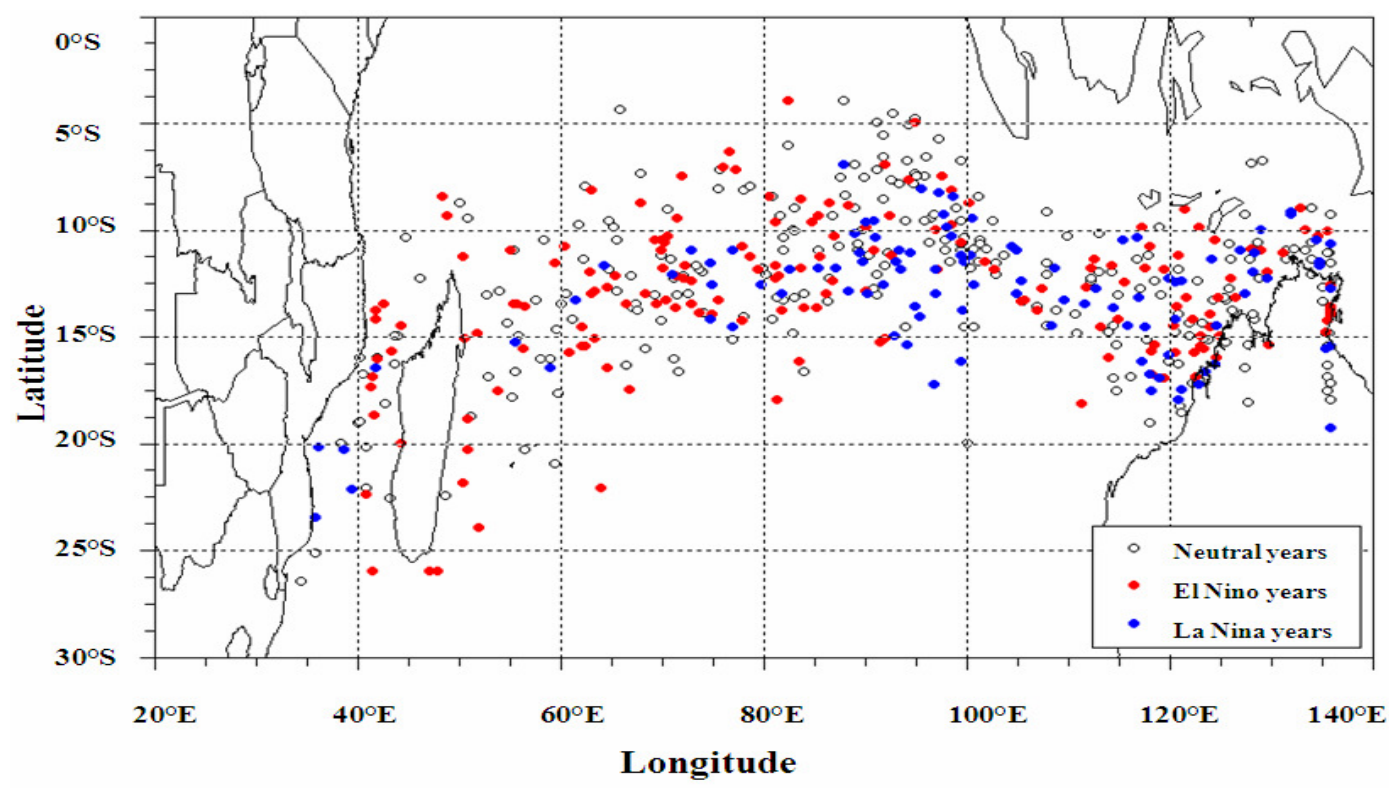

Fig. 1. Geographical distribution of tropical cyclogenesis events over the South Indian Ocean for the period 1969-2006.

of around $85^{\circ} \mathrm{E}$ ) with the maximum located around $\left[15^{\circ} \mathrm{S}\right.$, $\left.65^{\circ} \mathrm{E}\right]$ and it is below climatology in the eastern part of the basin (east of around $85^{\circ} \mathrm{E}$ ) with the minimum in the area centred around $\left[10^{\circ} \mathrm{S}, 95^{\circ} \mathrm{E}\right]$ (results in this area are significant at $90 \%$ level). To evaluate significance of the results, the Student t-test is employed in this study, with the null hypothesis that the anomaly is not significantly different from zero. It should be noticed that the results from this significance test need to be treated cautiously because of the relatively small size of TC data sample. As mentioned in the Introduction, the reliable TC records in the Southern Hemisphere start with the beginning of the satellite era in late 1960s-early 1970s. As an effort to increase the sample size, a relatively large grid box, $6^{\circ}$ by $6^{\circ}$, is selected for the analysis in this study. [Similar approach was applied by Chan (2000) for studying TC activity over the western North Pacific associated with El Niño and La Niña events.] A large area with test values greater than the specified significance threshold is likely to be true for individual seasons.

During La Niña episodes (Fig. 2b), increase of TC genesis is observed in the eastern part of the basin (east of about $85^{\circ} \mathrm{E}$ ) with a primary cyclogenesis maximum in the area located off the northwest coast of Western Australia around $\left[15^{\circ} \mathrm{S}, 120^{\circ} \mathrm{E}\right]$ and a secondary TC genesis maximum centred around $\left[15^{\circ} \mathrm{S}, 95^{\circ} \mathrm{E}\right]$ (both passed the significance test at $90 \%$ level).

\subsubsection{SST distribution}

Ocean thermal energy is an important contributor to TC genesis and according to Gray (1979) ocean temperatures greater than $26^{\circ} \mathrm{C}$ to a depth of $60 \mathrm{~m}$ is an essential climatological aspect of the seasonal frequency of TC formation at any location. To evaluate temperature's geographical distribution over the two oceanic basins, we firstly derived the SST climatology based on 1968 to 1996 period as defined by Physical Sciences Division, National Oceanic and Atmospheric Administration (NOAA web page). In the South Indian Ocean, during both warm and cold ENSO phases oceanic conditions in terms of SSTs above $26^{\circ} \mathrm{C}$ (Gray, 1979) are favourable over the near-equatorial belt between the equator and about $15^{\circ} \mathrm{S} \sim 25^{\circ} \mathrm{S}$ (figure not shown). Thus, it appears that changes in geographical distribution of SSTs over the basin related to warm and cold phases of ENSO rather than temperature values per se influence changes in TC genesis.

Analysing average SST anomaly fields (SSTAs) from November to April, it was found that positive SSTAs are present nearly over the whole range of longitudes between the equator and about $30-35^{\circ} \mathrm{S}$ during El Niño events except for a relatively small area around $\left[35^{\circ} \mathrm{S}, 60^{\circ} \mathrm{E}\right]$ (Fig. 3a; shaded areas indicate where statistical tests are significant at 95\% level). Strong positive anomalies are observed in the central parts of the basin with maximum values greater than $0.4^{\circ} \mathrm{C}$, which can contribute to increased TC genesis in those areas in El Niño seasons. The area of enhanced cyclogenesis located around $\left[15^{\circ} \mathrm{S}, 65^{\circ} \mathrm{E}\right]$ (Fig. $2 \mathrm{a}$ ) matches the significant positive SSTAs in the same region quite well.

During La Niña seasons, positive SSTAs observed over the basin in El Niño seasons (Fig. 3a) are replaced by negative SSTAs which are found over the most areas in the South Indian Ocean from the equator to about $30^{\circ} \mathrm{S}$ except for the central and southern areas off Western Australia coastline (Fig. 3b). This contrast in the SST distribution over the basin during La Niña seasons can partially explain displacement 
(a)

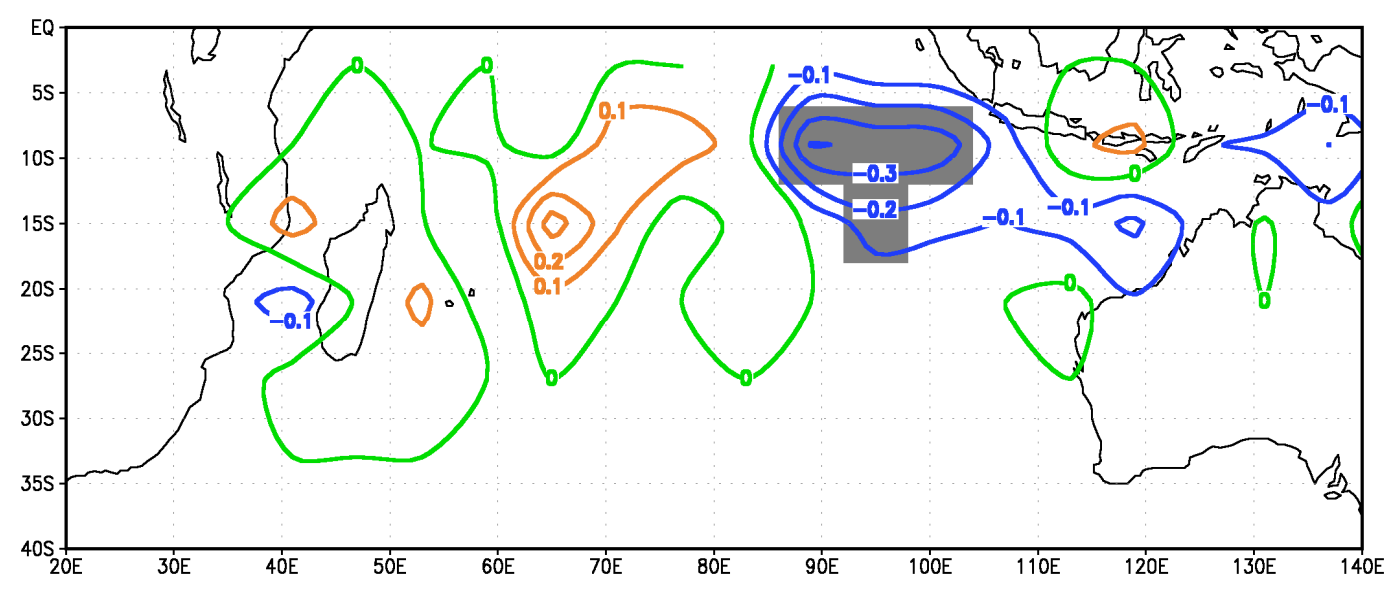

(b)

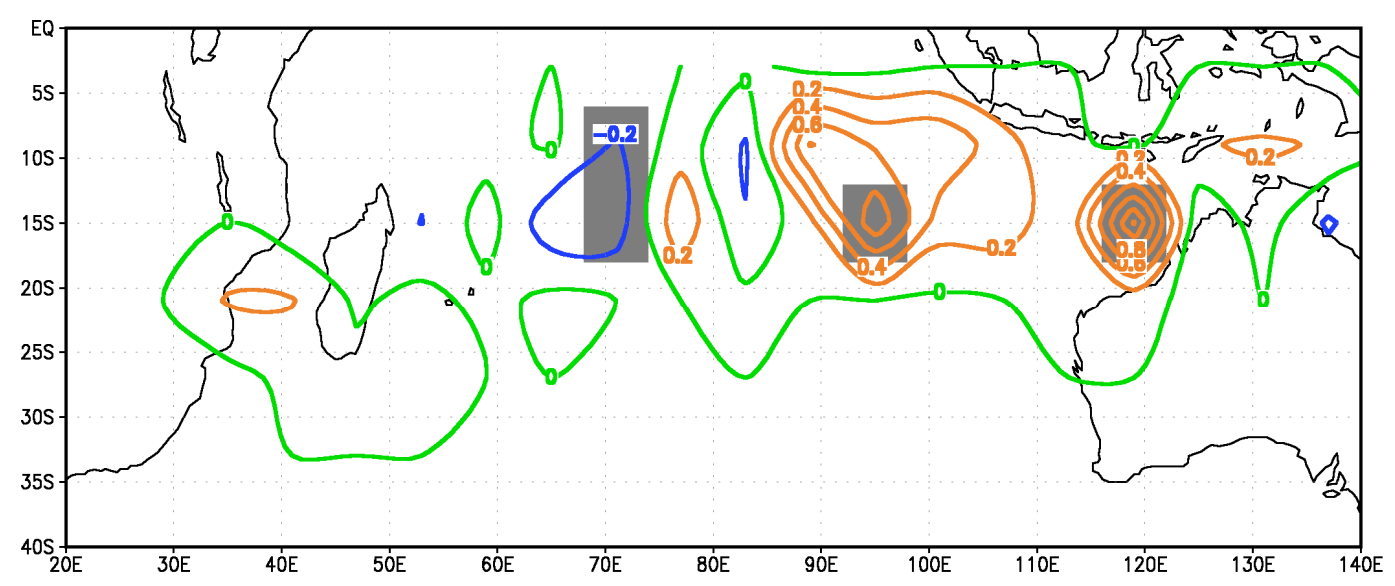

Fig. 2. Composite anomalies of the average annual number of tropical cyclogenesis in the South Indian Ocean during (a) El Niño and (b) La Niña episodes in $6^{\circ} \times 6^{\circ}$ boxes. The shades indicate areas where the statistical test is significant at the $90 \%$ level.

of area favourable for cyclogenesis to the eastern part of the basin closer to the coast of Western Australia (Fig. 2) where the warmer SSTs are present.

\subsubsection{Relative humidity}

High relative humidity is one of the key factors influencing TC development as it provides sufficient moisture at the lower level and in the mid-troposphere (4 to $8 \mathrm{~km}$ ) (Gray, 1979). Geographical distribution of mid-tropospheric relative humidity at $500 \mathrm{hPa}$ level during the period from November to April has been examined in this study. Results for El Niño events are shown in Fig. 4a. A large area with negative anomalies of relative humidity is observed between the equator and about $15^{\circ} \mathrm{S}$ (Fig. 4a), but it is noticed that most of the negative anomalies did not pass the significance test except for the some areas off Western Australia and over parts of In- donesia. The areas of negative anomalies of relative humidity are collocated with the areas of relatively weak anomalies of SSTs, which can additionally contribute to decreased TC activity in the eastern part of the basin (about $10^{\circ} \mathrm{S}, 95^{\circ} \mathrm{E}$ in Fig. 2a) during El Niño seasons.

Comparing results presented in Figs. $4 \mathrm{a}$ (El Niño) and $4 \mathrm{~b}$ (La Niña), significant relative humidity decrease in the central part of the basin (about $70^{\circ} \mathrm{E}$ ) was found during La Niña seasons, which is consistent with the decreased TC activity over this area evident from comparing Fig. $2 \mathrm{a}$ and b. During La Niña seasons, there is a large area with positive anomalies of relative humidity over the equatorial and tropical regions of the northwest of Australia and Indonesia from $85^{\circ} \mathrm{E}$ to $140^{\circ} \mathrm{E}$, with another positive anomaly area to the west of Madagascar (Fig. 4b), and large area for negative anomalies over the central part (around $20^{\circ} \mathrm{S}, 75^{\circ} \mathrm{E}$ ) of the basin. To the northwest of Australia, positive relative humidity anomalies 
(a)

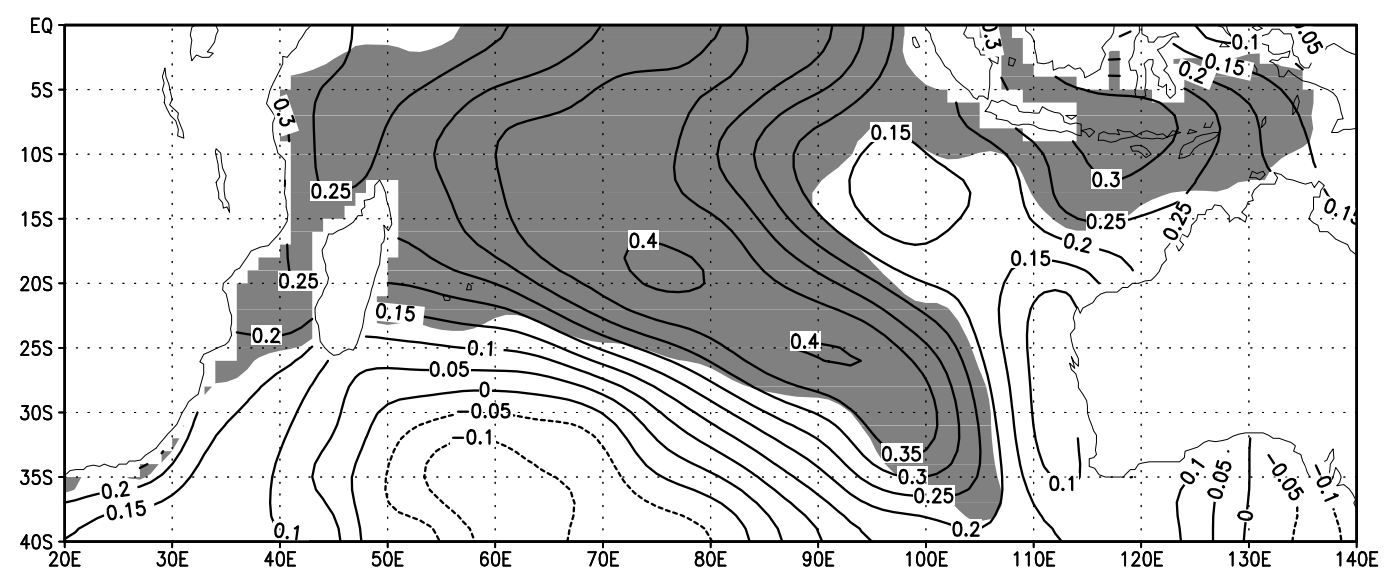

(b)

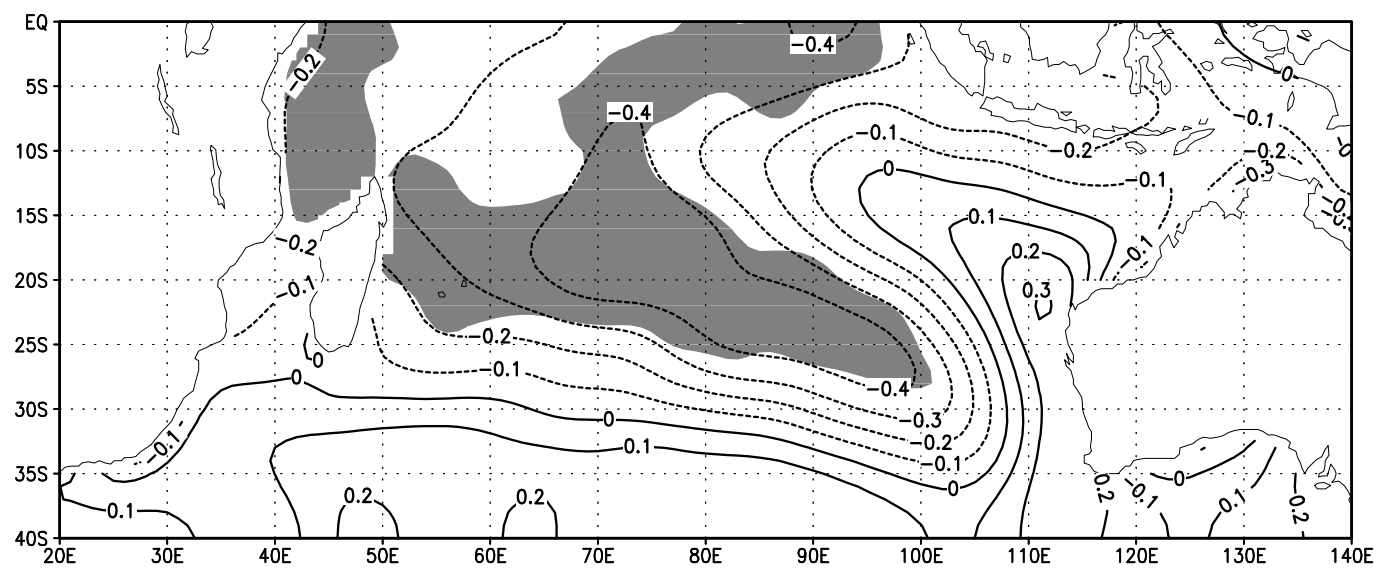

Fig. 3. SST anomalies $\left({ }^{\circ} \mathrm{C}\right)$ from November to April in the South Indian Ocean during (a) El Niño and (b) La Niña episodes. The shades indicate areas where the statistical test is significant at the $95 \%$ level.

and warmer SSTs both contributes towards increased TC activity during La Niña seasons.

\subsubsection{Vertical wind shear}

The vertical wind shear plays an important role in tropical cyclogenesis and development: strong vertical wind shear inhibits tropical cyclogenesis, while weak vertical shear favours TC genesis and development (DeMaria, 1996; Maloney and Hartmann, 2000; Zehr, 2003). It is well known that vertical wind-shear variations can have a significant impact on the interannual variability of TC activity in the Northern Hemisphere (e.g., Gray, 1984).

The vertical wind shear is defined here as the difference of magnitudes between the zonal wind fields at $200 \mathrm{hPa}$ and $850 \mathrm{hPa}$. Results of analysis are shown for El Niño and La Niña seasons in Fig. 5a and b, respectively. The vertical wind shear over the whole basin is slightly weaker during El Niño seasons than that during La Niña seasons, in particular over the central and eastern parts of the basin. In general, wind shear is relatively weak in the near-equatorial area. Also, in the western part of the basin (west of $70^{\circ} \mathrm{E}$ ) the wind shear is weaker than in the eastern part of the basin during both warm and cold ENSO episodes. Changes in this environmental factor are not easily interpreted in order to explain observed changes in TC activity.

\subsubsection{Vorticity}

The vorticity anomalies at 0.995 sigma level (surface level) from November to April during El Niño seasons are shown in Fig. 6a. Large area of positive (anticyclonic) vorticity anomalies at [about $5-15^{\circ} \mathrm{S}, 70-135^{\circ}$ E] which extends from the central part of the basin to the northwest coast of 
(a)

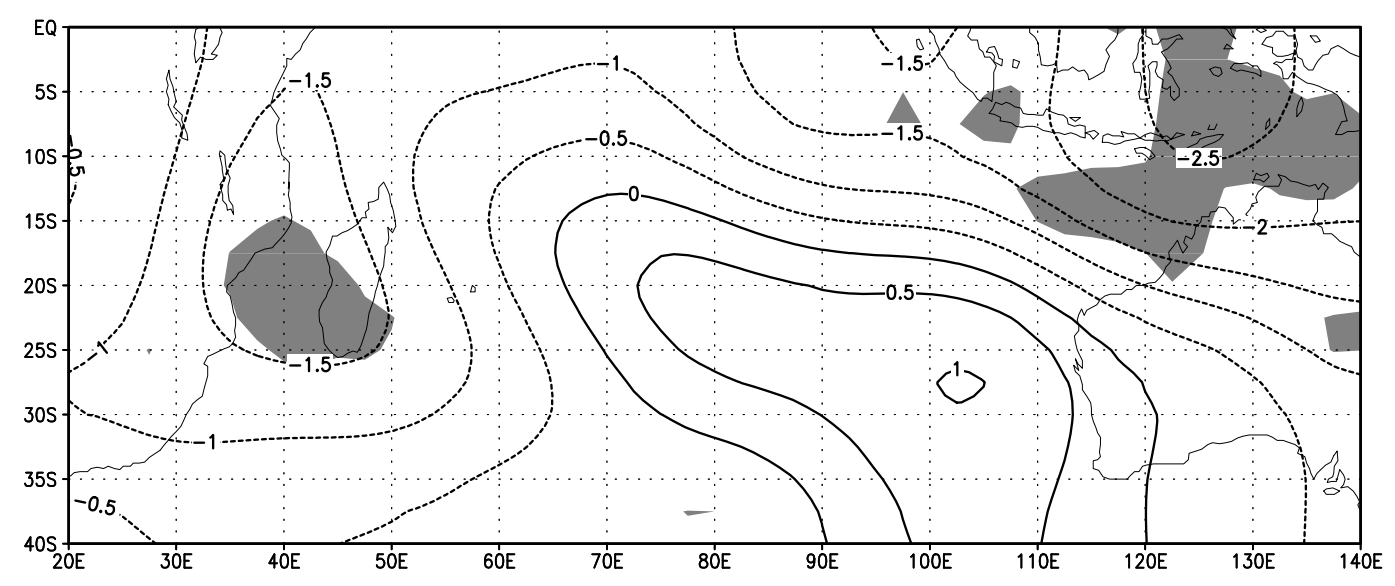

(b)

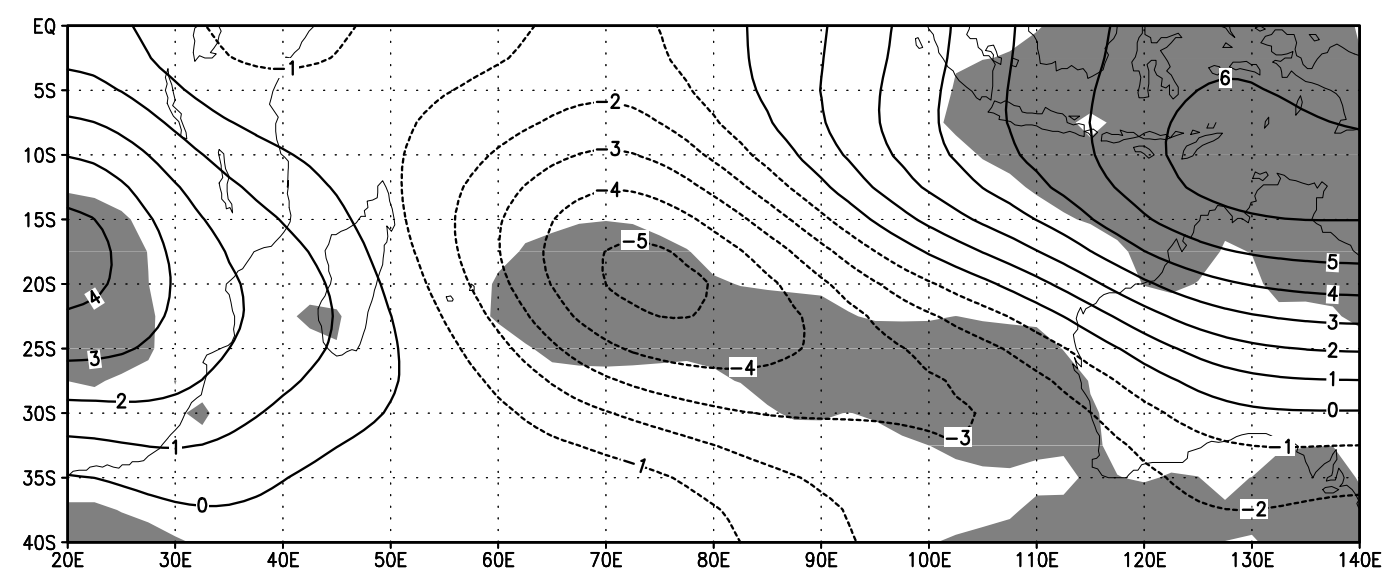

Fig. 4. Relative humidity anomalies (\%) at $500 \mathrm{hPa}$ over the South Indian Ocean for (a) El Niño and (b) La Niña episodes. The shades indicate areas where the statistical test is significant at the $95 \%$ level.

Australia is evident in Fig. 6a. However, centred around $\left[25^{\circ} \mathrm{S}, 65^{\circ} \mathrm{E}\right]$, there is a large area of negative (cyclonic) vorticity anomalies which are more favourable to tropical cyclogenesis. During El Niño seasons, the areas to the north of $15^{\circ} \mathrm{S}$ and east of $70^{\circ} \mathrm{E}$, are not favourable (in terms of vorticity impacts) to the TC genesis in comparison to the rest of the basin.

During La Niña seasons, negative (cyclonic) vorticity anomalies over the tropical areas of the central and eastern parts of the basin (Fig. 6b) replace the anticyclonic vorticity anomalies observed in this area during El Niño seasons (Fig. 6a). It additionally contributes to increase in cyclone activity in the eastern part of the basin during La Niña seasons. In the western part, cyclonic vorticity anomalies are also observed between Madagascar and mainland Africa.

\subsection{The South Pacific Ocean}

\subsubsection{Tropical cyclone genesis}

Spatial distribution of TC genesis over the South Pacific Ocean basin during all TC seasons from 1969 to 2006 is shown in Fig. 7. Points of cyclogenesis are observed over the range of longitudes between $135^{\circ} \mathrm{E}$ and $120^{\circ} \mathrm{W}$. We will refer to this domain as the basin in the following analysis of geographical distribution of TC genesis and influence of the large-scale environmental factors; area of the South Pacific Ocean east of $120^{\circ} \mathrm{W}$ will not be under consideration. A comparison between cyclogenesis events during El Niño, La Niña and neutral seasons (Fig. 7) reveals that points of TC genesis are displaced towards southwest during La Niña seasons compared to El Niño seasons. This result is in agreement with previous studies on TCs in the Southwest Pacific Ocean (Gray, 1988; Basher and Zheng, 1995). 
(a)

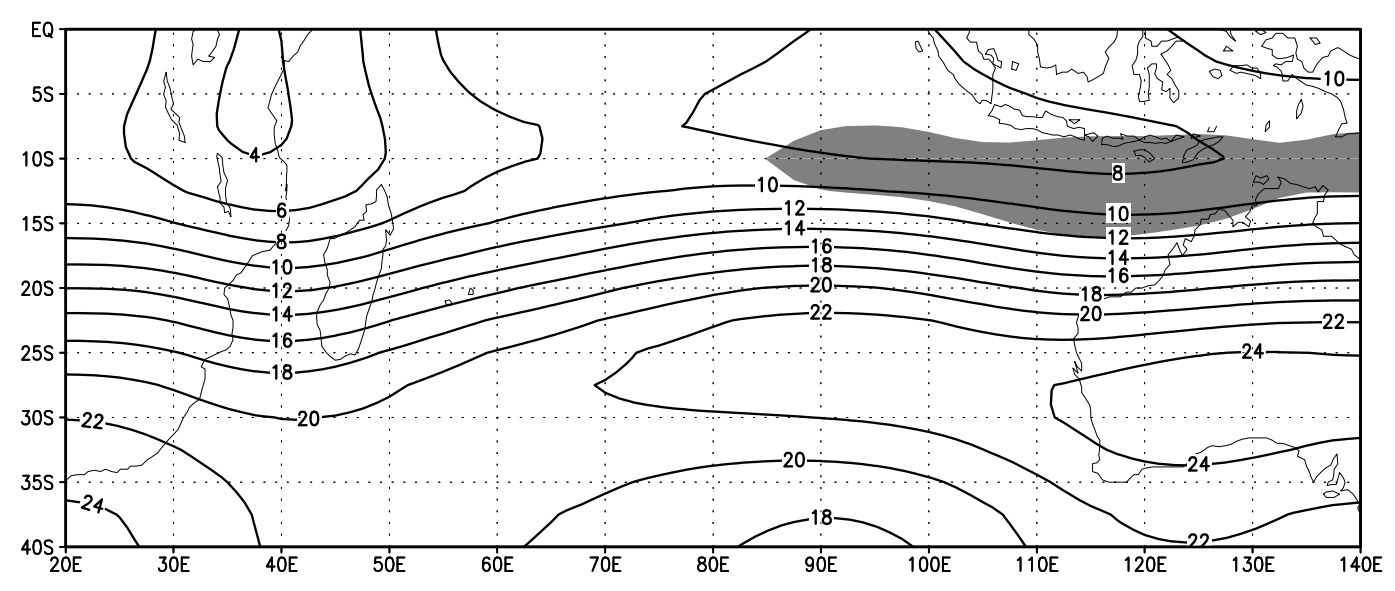

(b)

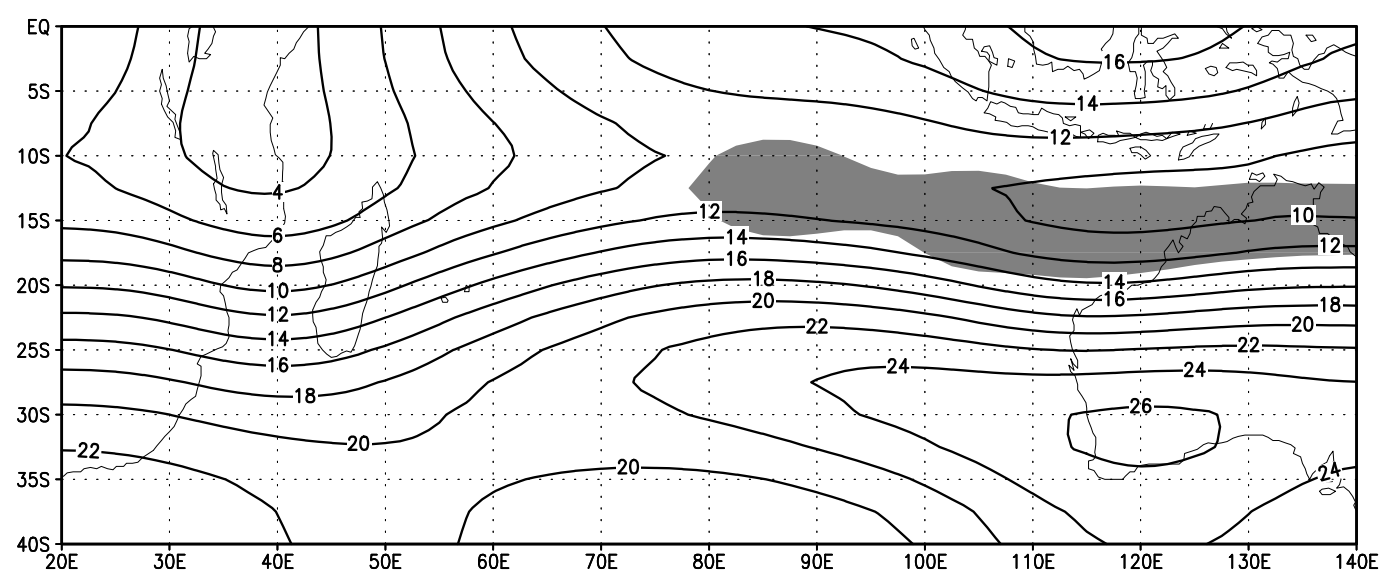

Fig. 5. Zonal wind shear $\left(U_{200}-U_{850}\right)\left(\mathrm{m} \mathrm{s}^{-1}\right)$ over the South Indian Ocean for (a) El Niño and (b) La Niña episodes. The shades indicate areas where the statistical test is significant at the $95 \%$ level.

Analysis of spatial distribution of tropical cyclogenesis during the El Niño seasons (Fig. 8a) shows that a large area of above climatology TC genesis is located in the eastern part of the basin east of the line $\left[10^{\circ} \mathrm{S}, 165^{\circ} \mathrm{E}-20^{\circ} \mathrm{S}, 175^{\circ} \mathrm{E}\right]$. During La Niña seasons (Fig. 8b), area of active TC genesis is displaced southwest to around $\left[10-20^{\circ} \mathrm{S}, 145-170^{\circ} \mathrm{E}\right]$ (statistically significant at 90\% level) and TC activity in the central near-equatorial area of the basin around $\left[5-15^{\circ} \mathrm{S}\right.$, $170^{\circ} \mathrm{E}-170^{\circ} \mathrm{W}$ ] is below the climatology.

\subsubsection{SST distribution}

During El Niño seasons, the SSTAs are positive in the nearequatorial area and in the eastern part of the basin, with maximum positive anomalies in the area around $\left[0-15^{\circ} \mathrm{S}, 160^{\circ} \mathrm{E}-\right.$ $140^{\circ} \mathrm{W}$ ] (Fig. 9a), while across the Coral Sea, there is a narrow zone of negative anomalies extending southeastward to the central and eastern parts of the basin. The positive SSTAs promote TC genesis and development further eastwards in the basin in El Niño seasons when compared with La Niña seasons (Fig. 8). During La Niña seasons, negative SSTAs replacing a large area between the equator and $15^{\circ} \mathrm{S}$ (Fig. 9b) inhibit TC genesis and contribute to displacing area preferable for TC genesis southwest compared to El Niño seasons (Fig. 8b). Warmer than climatological average waters found in the area from the Coral Sea to the central and eastern parts of the basin during La Niña seasons favour increase of TC activity in the western part of the basin as well as in the central part.

\subsubsection{Relative humidity}

Relative humidity anomalies at $500 \mathrm{hPa}$ during warm and cold phases of the ENSO are shown in Fig. 10a and b, 
(a)

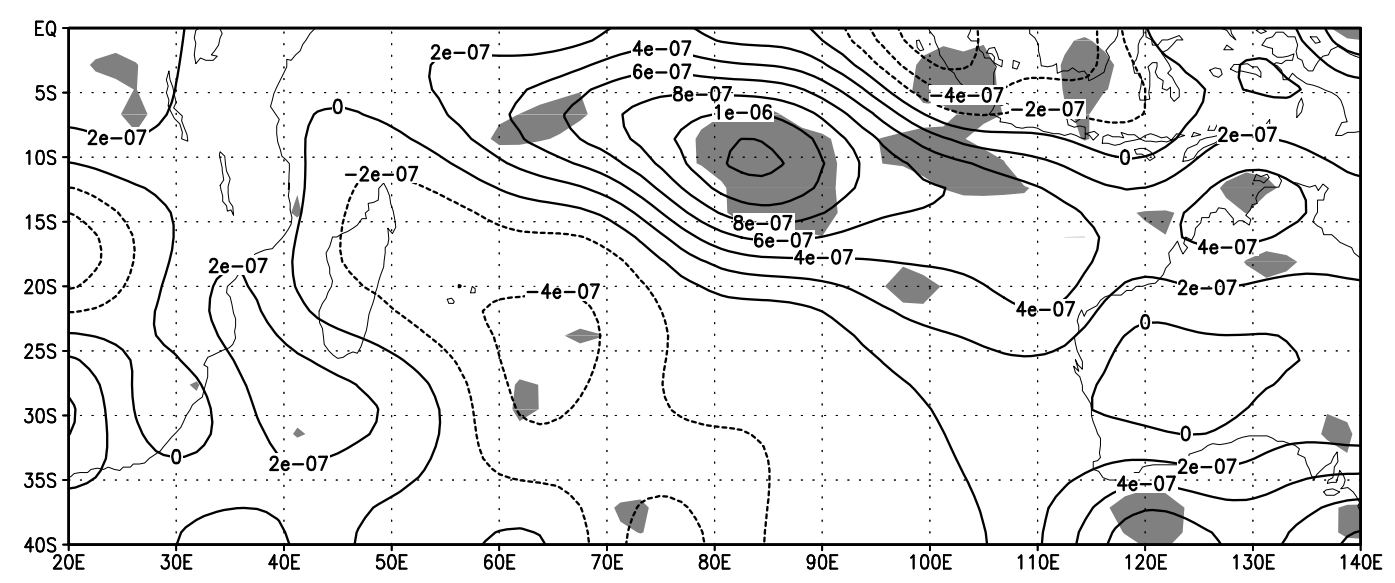

(b)

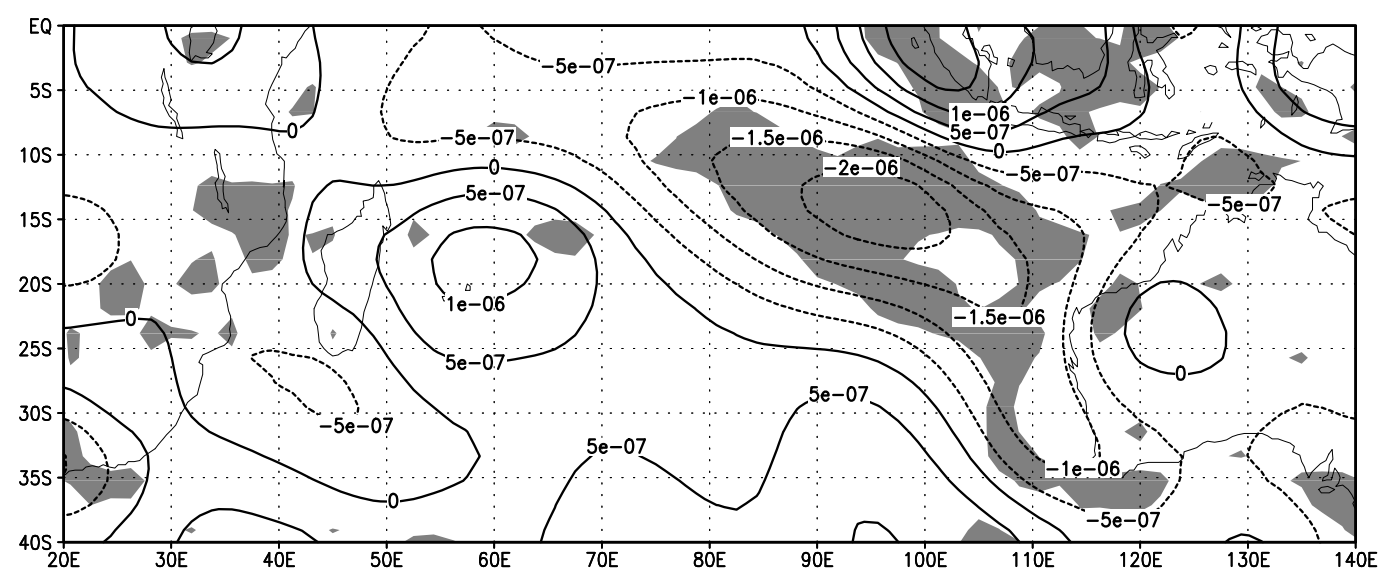

Fig. 6. Vorticity anomalies at 0.995 sigma level $\left(\mathrm{s}^{-1}\right)$ over the South Indian Ocean for (a) El Niño and (b) La Niña episodes. The shades indicate areas where the statistical test is significant at the $95 \%$ level.

respectively. During El Niño years, an area of positive relative humidity anomalies is located east of dateline between the equator and about $10^{\circ} \mathrm{S}$, which is a classical pattern for El Niño events (Fig. 10a). A large drier zone of relative humidity is observed southwest to the positive anomalies, with a minimum centre in the central part of the basin. Over the Coral Sea, significant negative anomalies are also observed, where TC activity is weaker. During La Niña events, the geographical distribution of relative humidity anomalies is the opposite; they are positive over a large area extending from the Coral Sea to the central part of the basin, significant at 95\% level (Fig. 10b), corresponding well with the increased TC activities over the western and central parts of the basin (Fig. 8b).

\subsubsection{Vertical wind shear}

During the ENSO warm phase (Fig. 11a), a zone of relatively weak vertical wind shear $\left(<8 \mathrm{~ms}^{-1}\right)$ located over most of the equatorial and tropical areas of the basin with the contour of $10 \mathrm{~ms}^{-1}$ located at $13^{\circ} \mathrm{S}$ to $14^{\circ} \mathrm{S}$ in the western and central part of the basin. During the ENSO cold phase (Fig. 11b), the zone of relatively weak wind shear moves westwards with a minimum centre at about $160^{\circ} \mathrm{E}$ to $175^{\circ} \mathrm{E}$. The contour of $10 \mathrm{~m}^{-1}$ moves southwards to about $15^{\circ} \mathrm{S}$ to $20^{\circ} \mathrm{S}$ across the whole basin. This spatial distribution of vertical wind shear contributes to increased TC activity over the area west of the dateline and shifting area of enhanced cyclogenesis and TC development closer to Australia during La Niña seasons. 


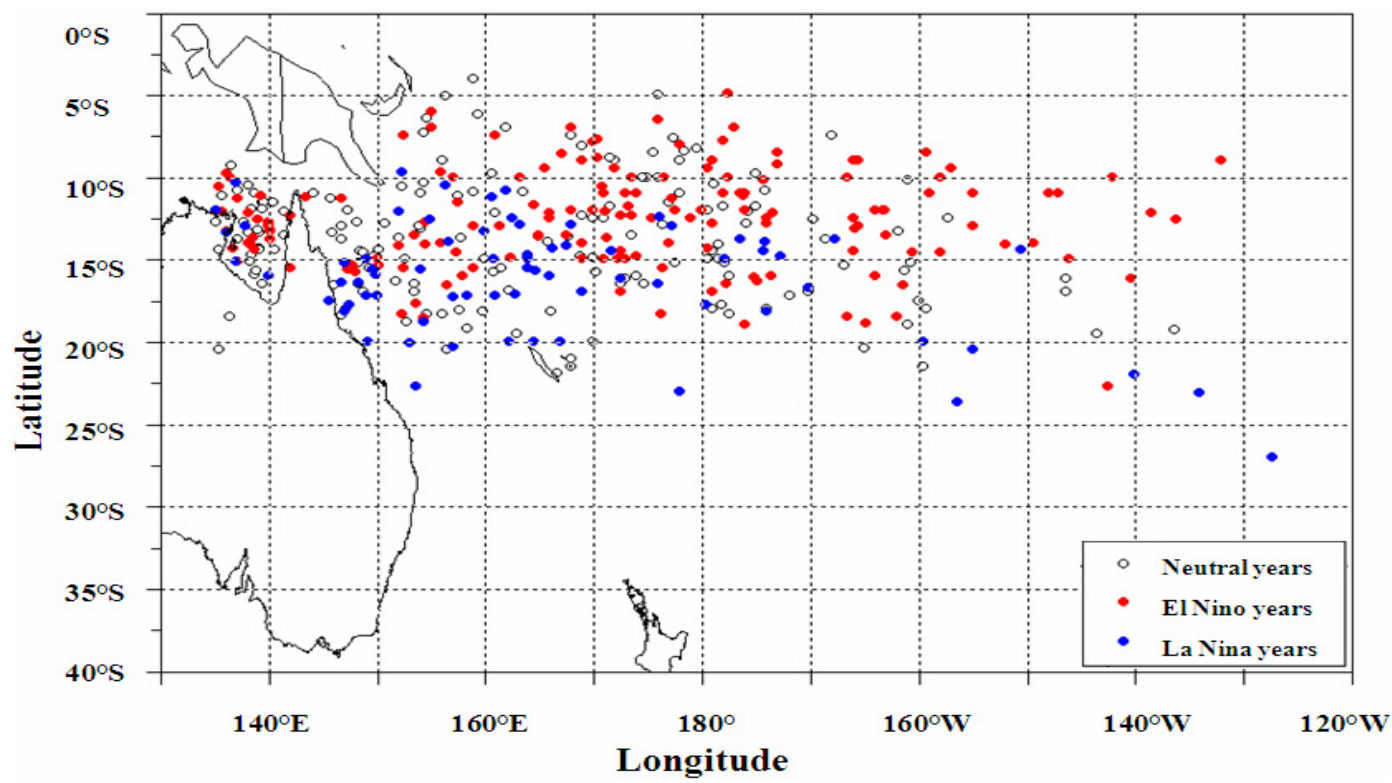

Fig. 7. Geographical distribution of tropical cyclogenesis events over the South Pacific Ocean for the period 1969-2006.

\subsubsection{Vorticity}

Vorticity anomalies at 0.995 sigma level during warm and cold phases of the ENSO are shown in Fig. 12a and b, respectively. For El Niño seasons, negative vorticity anomalies dominate over the near-equatorial areas, with a minimum centre located at about $10^{\circ} \mathrm{S}$ to $175^{\circ} \mathrm{W}$, and positive anomalies of vorticity are observed to the south over latitudes from about $15^{\circ} \mathrm{S}$ to $35^{\circ} \mathrm{S}$ across the whole basin (Fig. 12a). Cyclonic (negative) vorticity anomalies in the area $\left[5-15^{\circ} \mathrm{S}\right]$ favour cyclogenesis in the near-equatorial areas and contribute to increased TC activity in the eastern part of the basin in El Niño seasons. For La Niña seasons, spatial distribution of vorticity anomalies is the opposite: positive anomalies are located over the near-equatorial areas and negative anomalies are observed to the south (Fig. 12b). This geographical distribution of vorticity anomalies contributes to restraining TC genesis in areas close to the equator but promotes cyclogenesis in the Australian region in La Niña seasons.

\section{Discussion and summary}

ENSO is a coupled ocean-atmosphere phenomenon and changes in oceanic conditions associated with El Niño and La Niña events are coupled with changes in atmospheric circulation. During the ENSO warm phase, an El Niño event, changes in large-scale environmental conditions such as weakening the Walker circulation (this manifests in weakening the easterly trade winds, rise in air pressure over the Indian Ocean, Indonesia and Australia and fall in air pressure over the central and eastern Pacific Ocean) and displacing warm water in the Pacific (i.e. cooling water in the western Pacific and warming water in the central and eastern equatorial Pacific) occur. During the ENSO cold phase, a La Niña event, the trade winds strengthen, warmer water accumulates in far western Pacific and cold pool in the eastern Pacific intensifies resulting in equatorial SSTs being cooler than climatological average.

In this study, changes in tropical cyclogenesis over the South Indian and South Pacific Oceans related to changes in large-scale environmental factors associated with the warm and cold phases of the ENSO phenomenon have been investigated. The physical mechanism by which changes in TC activity are related to the environment has been explored. Warm equatorial water provides thermal energy necessary for TC genesis (Gray, 1979) and therefore variation in geographical distribution of SSTs related to changes of the ENSO phases was examined. Large-scale vertical motion which provides convection was examined through analysing relative humidity in mid-troposphere. Positive (negative) anomalies of mid-tropospheric relative humidity which characterize upward (downward) large-scale vertical motion enhance (reduce) TC genesis. The negative effect of vertical wind shear on TC genesis and intensification is well documented (Gray, 1968; Merrill, 1988). As ENSO affects the strength of easterly and westerly winds in nearequatorial area, these variations in zonal flow are associated with changes in low-level relative vorticity fields. Consequently, influence of the key environmental factors such as SSTs, relative humidity in mid-troposphere, vertical wind shear and lower tropospheric vorticity on TC genesis have been examined.

Over the South Indian Ocean, TC genesis occurs over most of the basin with maximum cyclogenesis in the area 
(a)

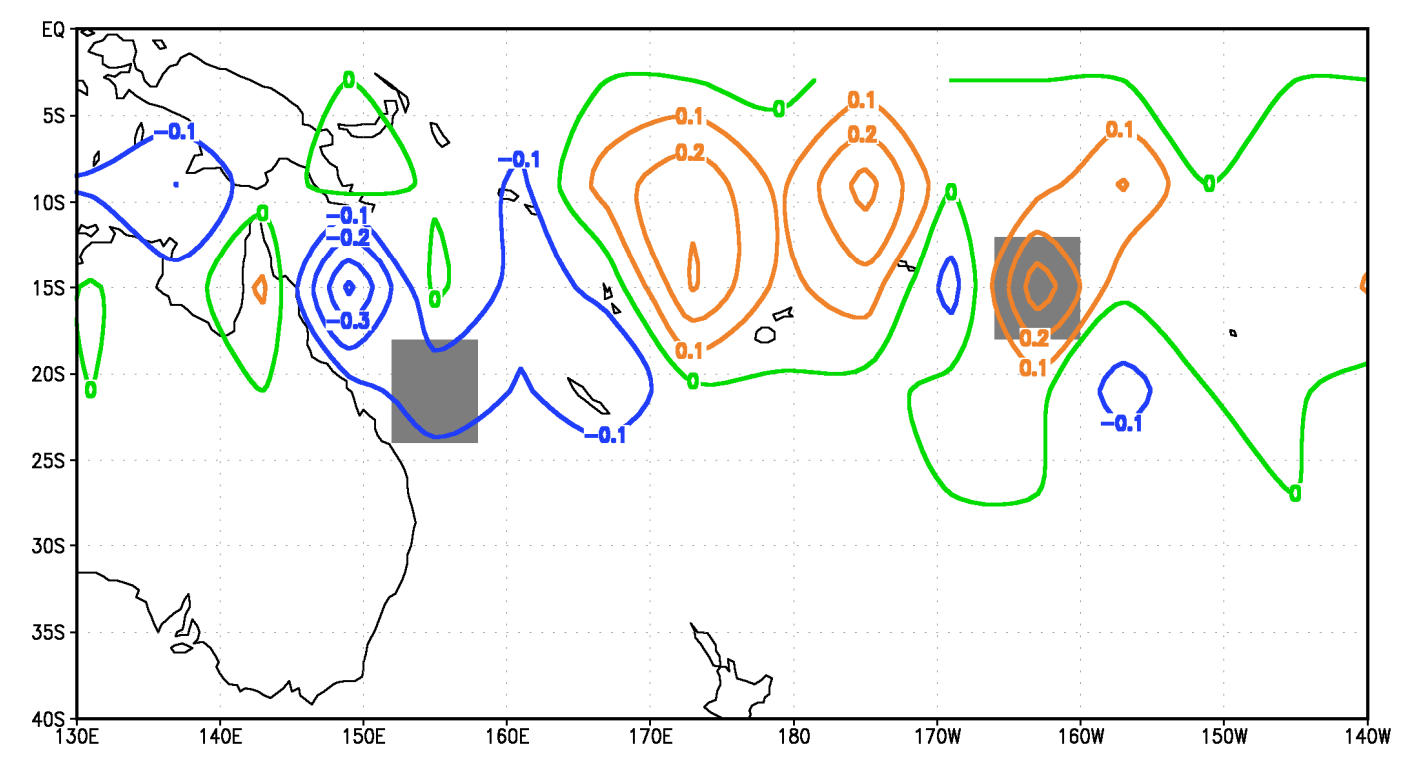

(b)

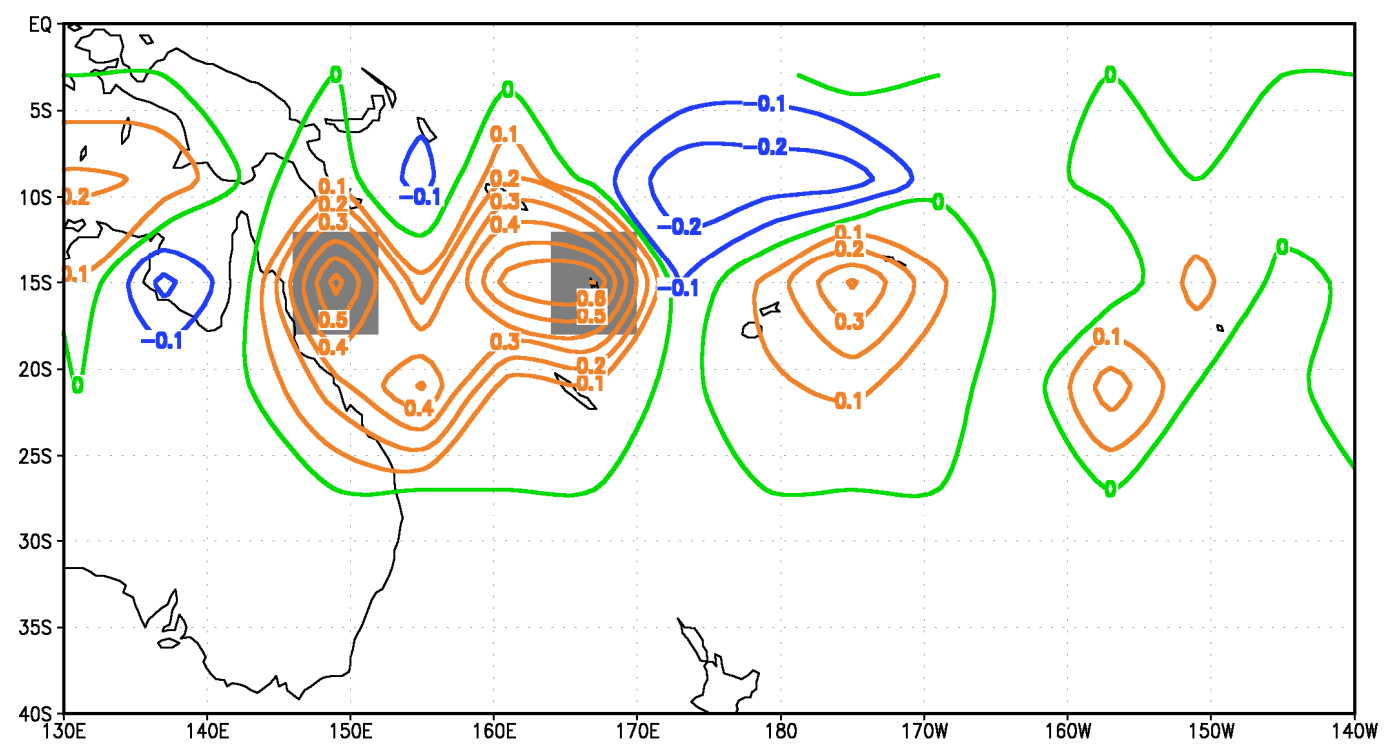

Fig. 8. Composite anomalies of the average annual number of tropical cyclogenesis in the South Pacific Ocean during (a) El Niño and (b) La Niña episodes in $6^{\circ} \times 6^{\circ}$ boxes. The shades indicate areas where the statistical test is significant at the $90 \%$ level.

$\left[5-15^{\circ} \mathrm{S}, 60-130^{\circ} \mathrm{E}\right]$. In the central part of the basin, only a small number of cyclogenesis events are found south of $15^{\circ} \mathrm{S}$. However, in the eastern part of the basin (east of $\left.105^{\circ} \mathrm{E}\right)$ maximum $\mathrm{TC}$ genesis is located in the area between $10^{\circ} \mathrm{S}$ and $20^{\circ} \mathrm{S}$, and in the western part of the basin (between African coast and $60^{\circ} \mathrm{E}$ ) area favourable to TC genesis occupies range of latitudes from $10^{\circ} \mathrm{S}$ to $25^{\circ} \mathrm{S}$.

During El Niño episodes, TC genesis is above climatology over the western part of the basin and below climatology over the eastern part, while during La Niña episodes it is the opposite. TC genesis also tends to occur further away from the equator during La Niña episodes compared to El Niño episodes.

In the eastern part of the basin near the coast of Western Australia, enhanced TC activity is observed in La Niña seasons compared to El Niño episodes. A number of large-scale environmental factors contribute to increase in cyclogenesis. During El Niño episodes, positive (anticyclonic) vorticity 
(a)

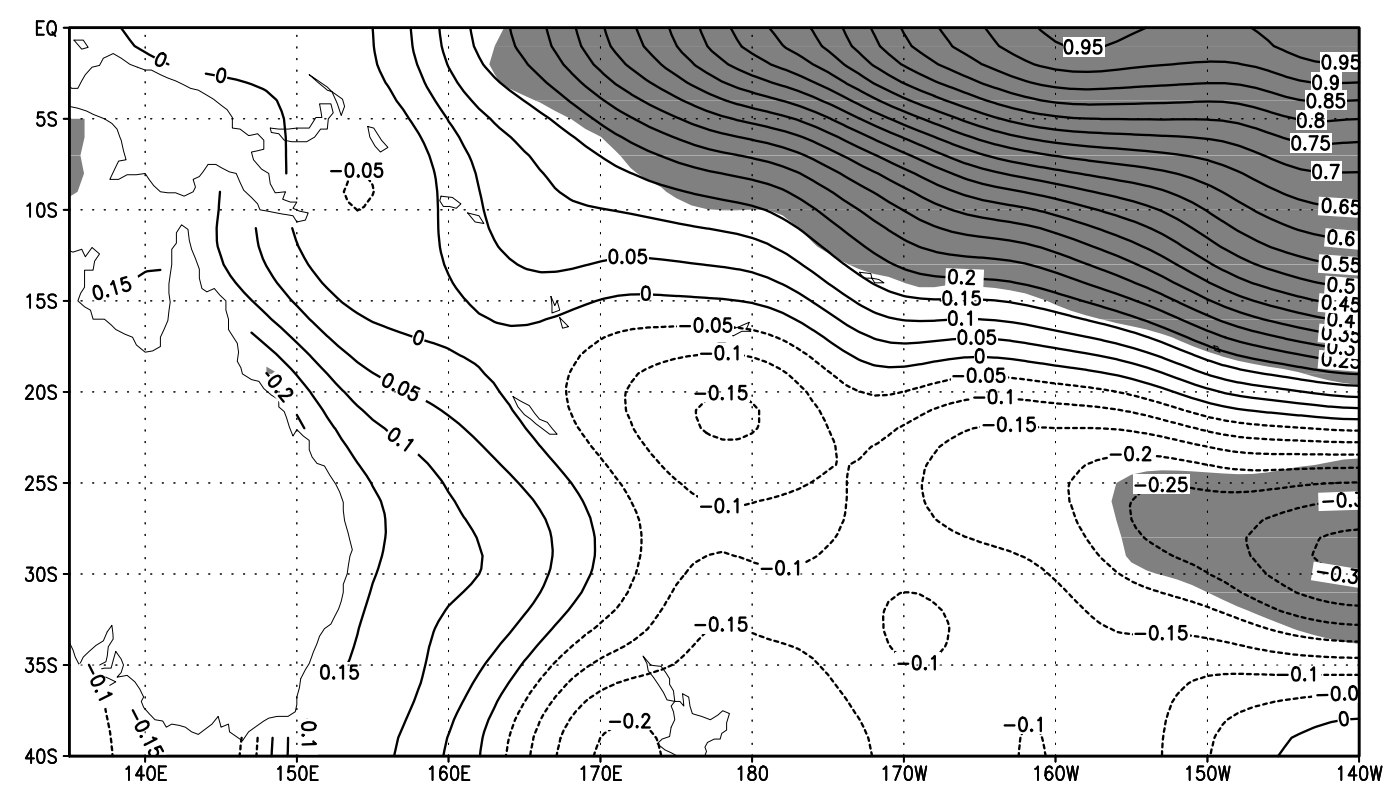

(b)

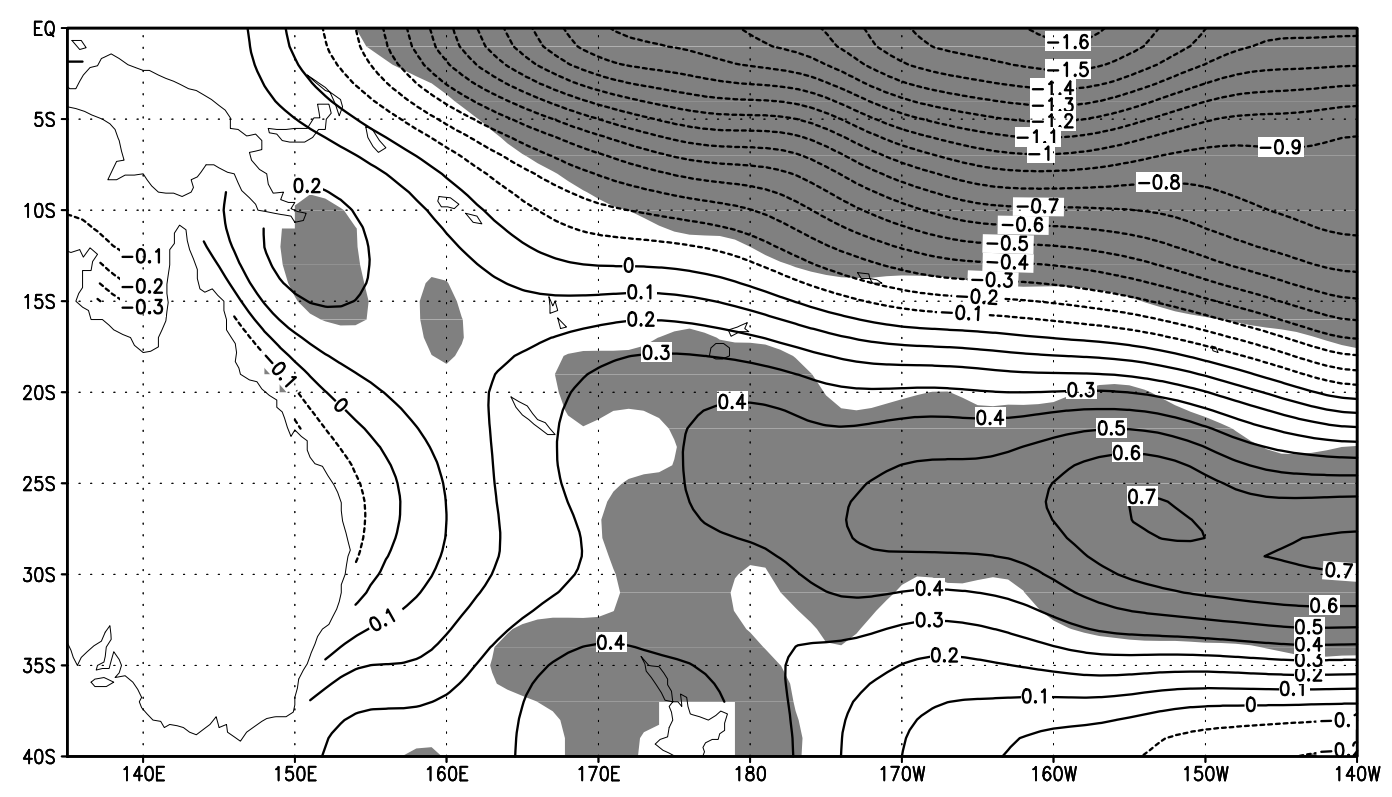

Fig. 9. SST anomalies $\left({ }^{\circ} \mathrm{C}\right)$ from November to April in the South Pacific Ocean during (a) El Niño and (b) La Niña episodes. The shades indicate areas where the statistical test is significant at the $95 \%$ level.

anomalies, negative relative humidity anomalies, and relatively weak positive anomalies of SSTs are observed over this area; all these factors contribute to suppressing TC genesis. On the contrary, negative (cyclonic) vorticity anomalies, positive relative humidity anomalies, and positive anomalies of SSTs observed during La Niña episodes enhance cyclogenesis in this area.
Positive vorticity anomalies contribute to inhibiting TC cyclogenesis in the western part of the basin during La Niña episodes. Negative SSTAs in the central part of the basin (around $70^{\circ} \mathrm{E}$ ) during La Niña episodes additionally reduce TC genesis in this part the South Indian Ocean in La Niña seasons compared to El Niño seasons. 
(a)

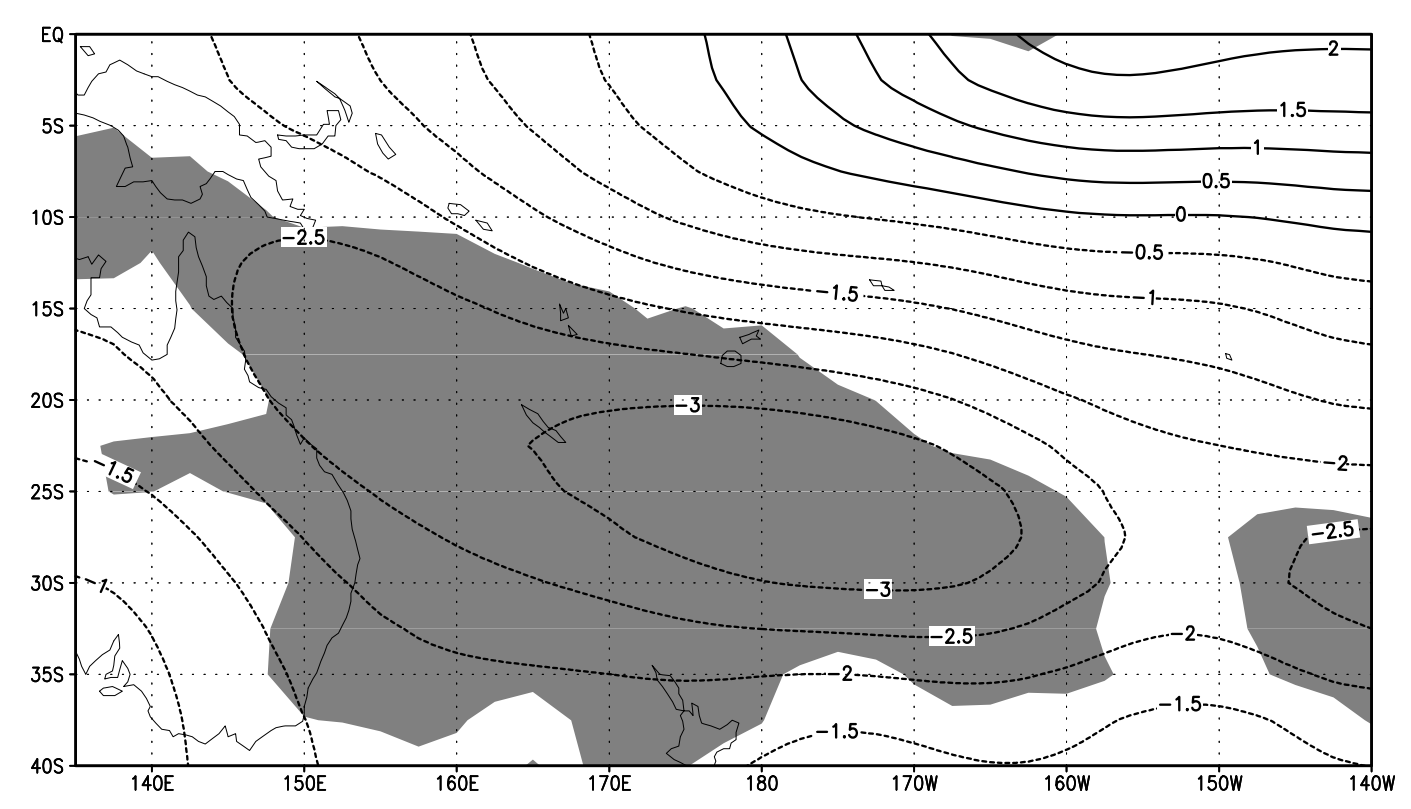

(b)

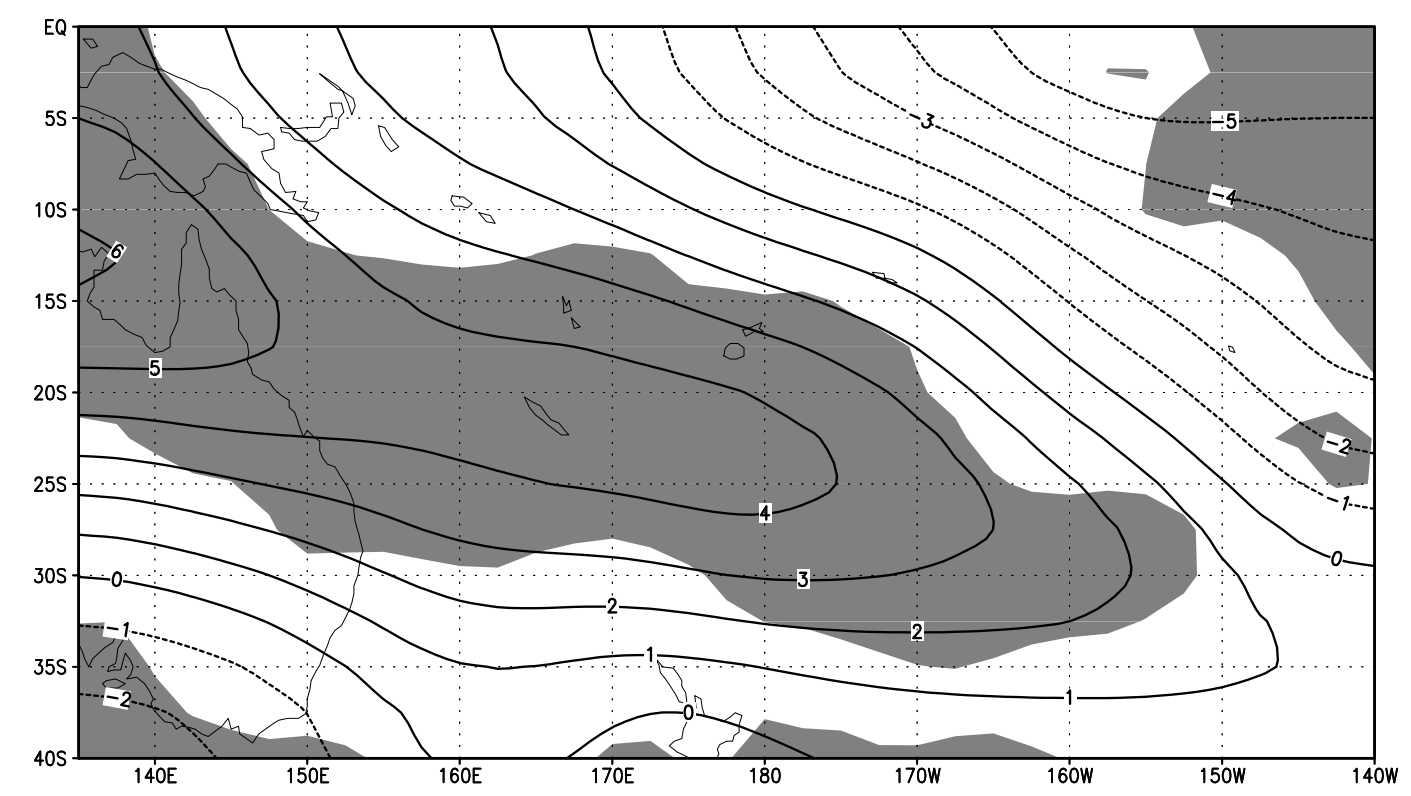

Fig. 10. Relative humidity anomalies (\%) at $500 \mathrm{hPa}$ over the South Pacific Ocean for (a) El Niño and (b) La Niña episodes. The shades indicate areas where the statistical test is significant at the $95 \%$ level.

In the South Pacific Ocean, tropical cyclogenesis is observed over the range of longitudes between $135^{\circ} \mathrm{E}$ and $120^{\circ} \mathrm{W}$. During El Niño episodes, area of above climatology TC genesis is located in the eastern part of the basin east of the line $\left[10^{\circ} \mathrm{S}, 165^{\circ} \mathrm{E}-20^{\circ} \mathrm{S}, 175^{\circ} \mathrm{E}\right]$. During La Niña episodes, TC genesis occurs further away from the equator compared to El Niño episodes, and TC activity is displaced to the western part of the basin closer to Australia. In general, southwest (northeast) shift of points of cyclogenesis during La Niña (El Niño) episodes is observed.

During El Niño (La Niña) episodes, positive (negative) SSTAs in the eastern part of the basin and in the 
(a)

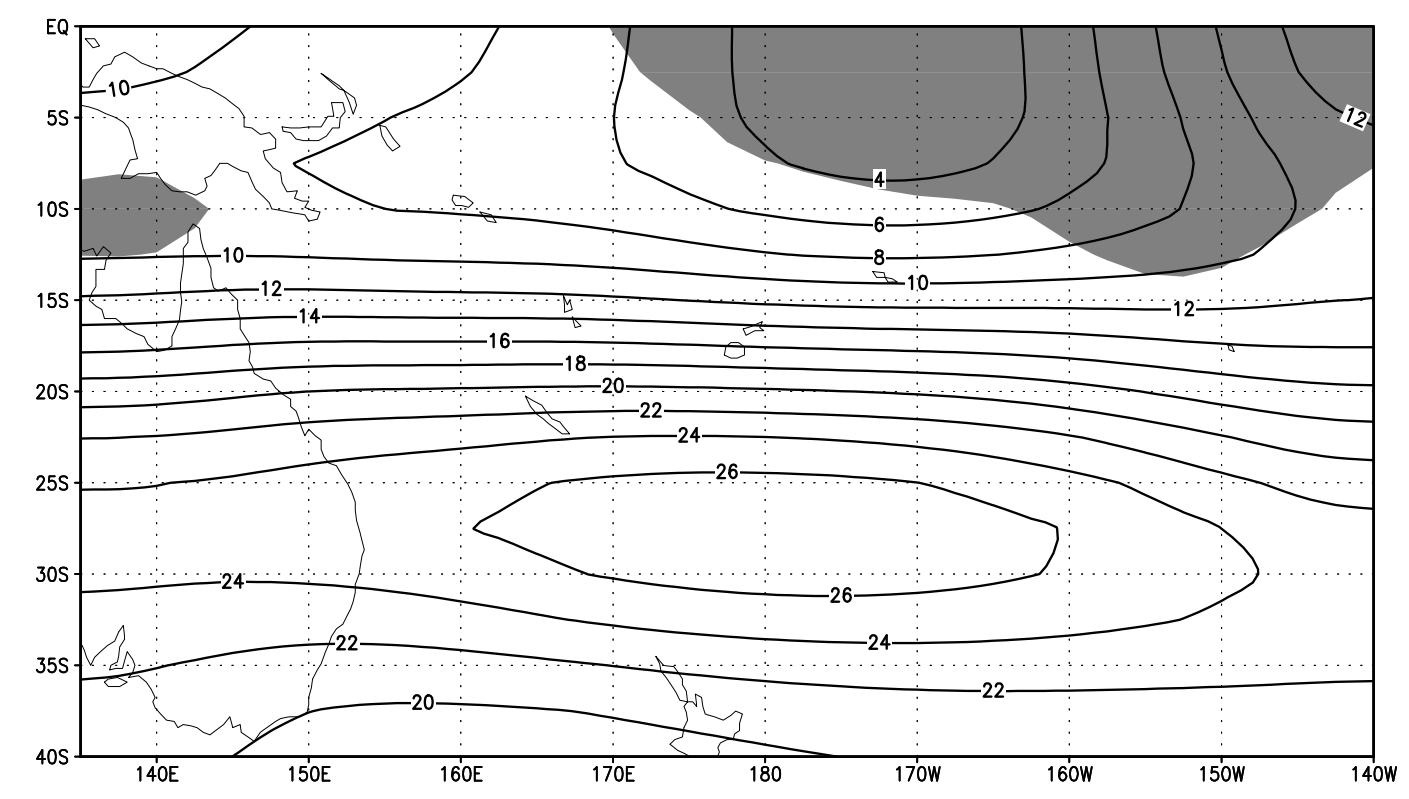

(b)

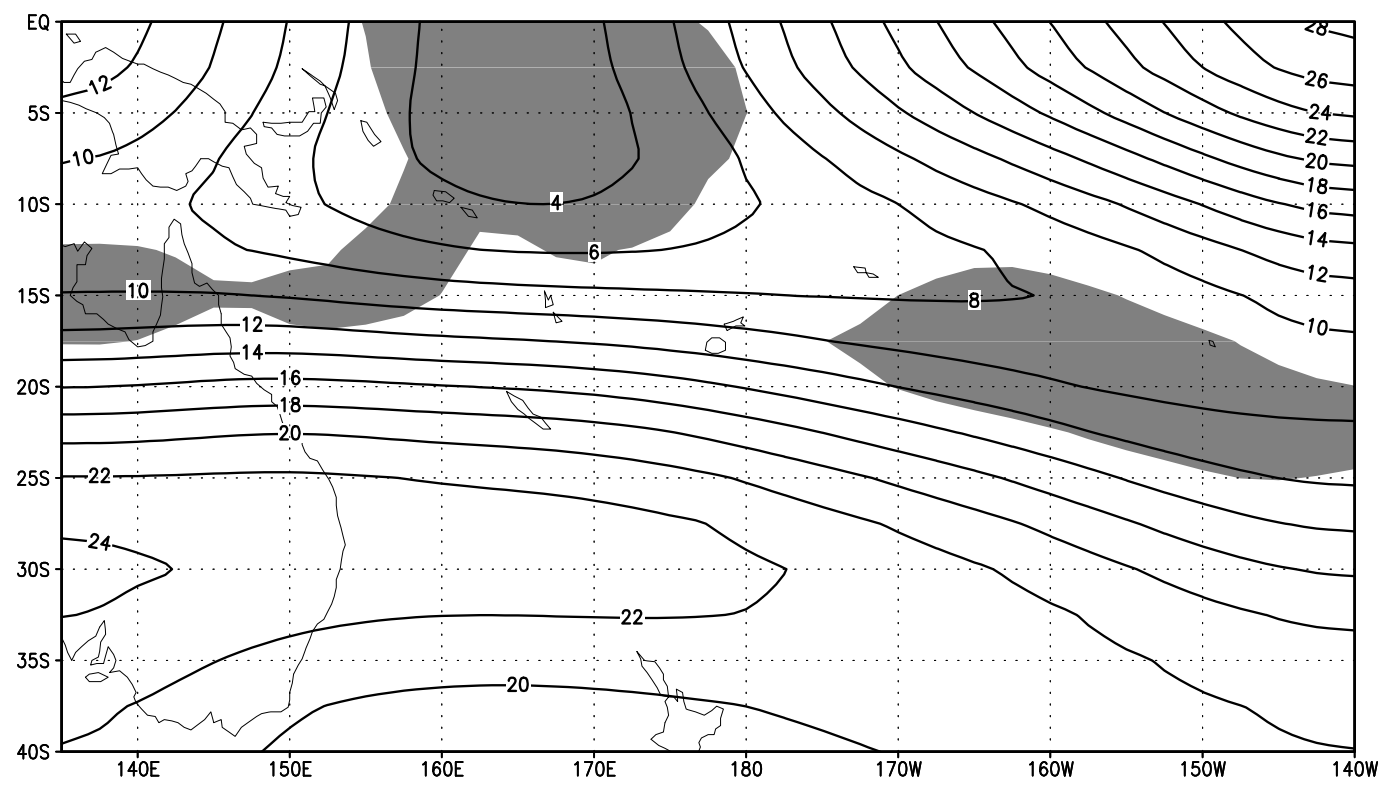

Fig. 11. Zonal wind shear $\left(U_{200}-U_{850}\right)\left(\mathrm{m} \mathrm{s}^{-1}\right)$ over the South Pacific Ocean for (a) El Niño and (b) La Niña episodes. The shades indicate areas where the statistical test is significant at the $95 \%$ level.

near-equatorial region promote (inhibit) TC genesis and development in the eastern part of the basin and contribute to displacing area preferable for TC genesis closer to (away from) the equator. During La Niña episodes, warmer waters in the southwestern part of the basin favour increase of TC activity in the western part of the basin, closer to Australia. The variations of the relatively humidity fields at $500 \mathrm{hPa}$ which consistent with variations in SSTs contribute significantly to changes in cyclogenesis over the basin.

Cyclonic vorticity anomalies are another factor which favours increased TC activity in the central and eastern part of the basin in El Niño episodes. In La Niña episodes, anticyclonic vorticity anomalies located over the near-equatorial region contribute to decrease in TC genesis in the area close 
(a)

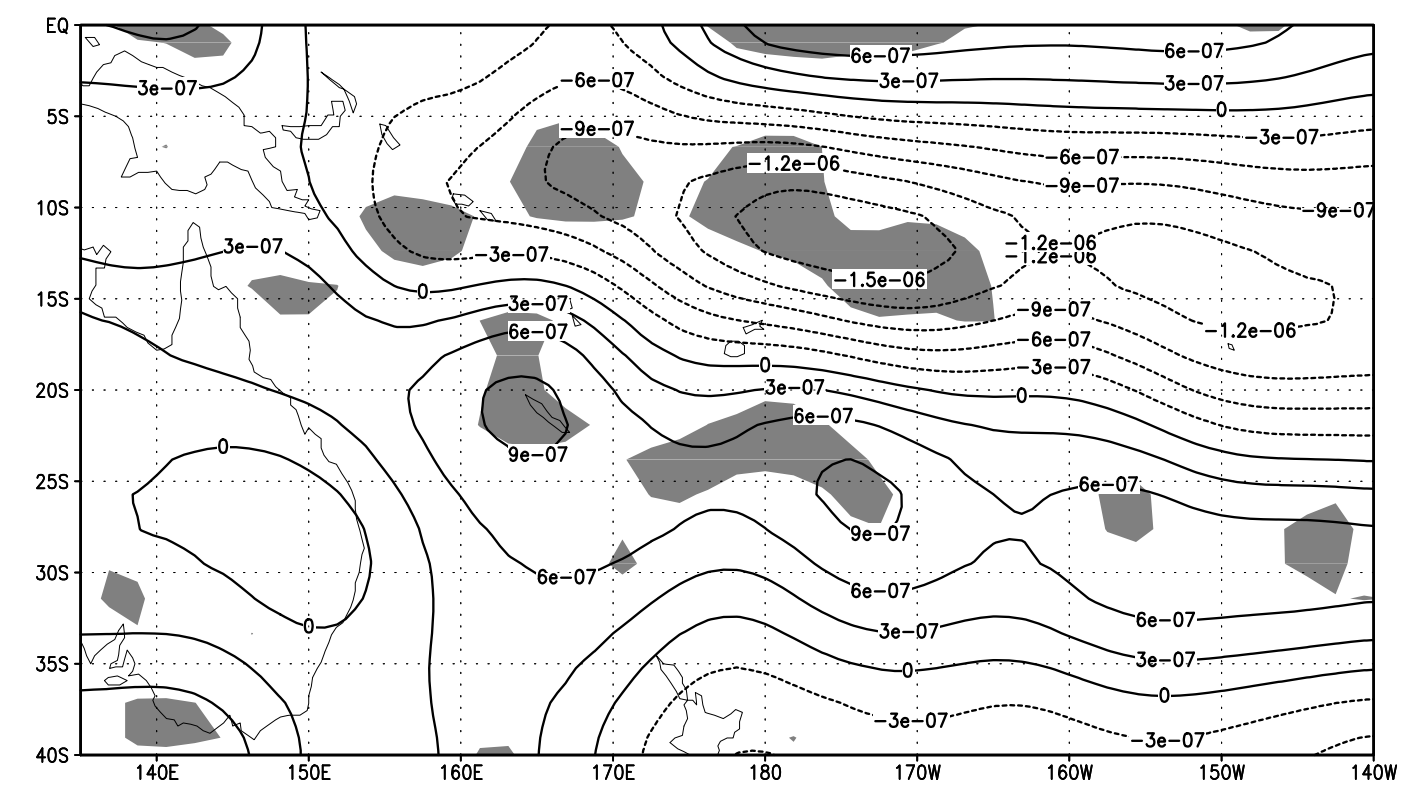

(b)

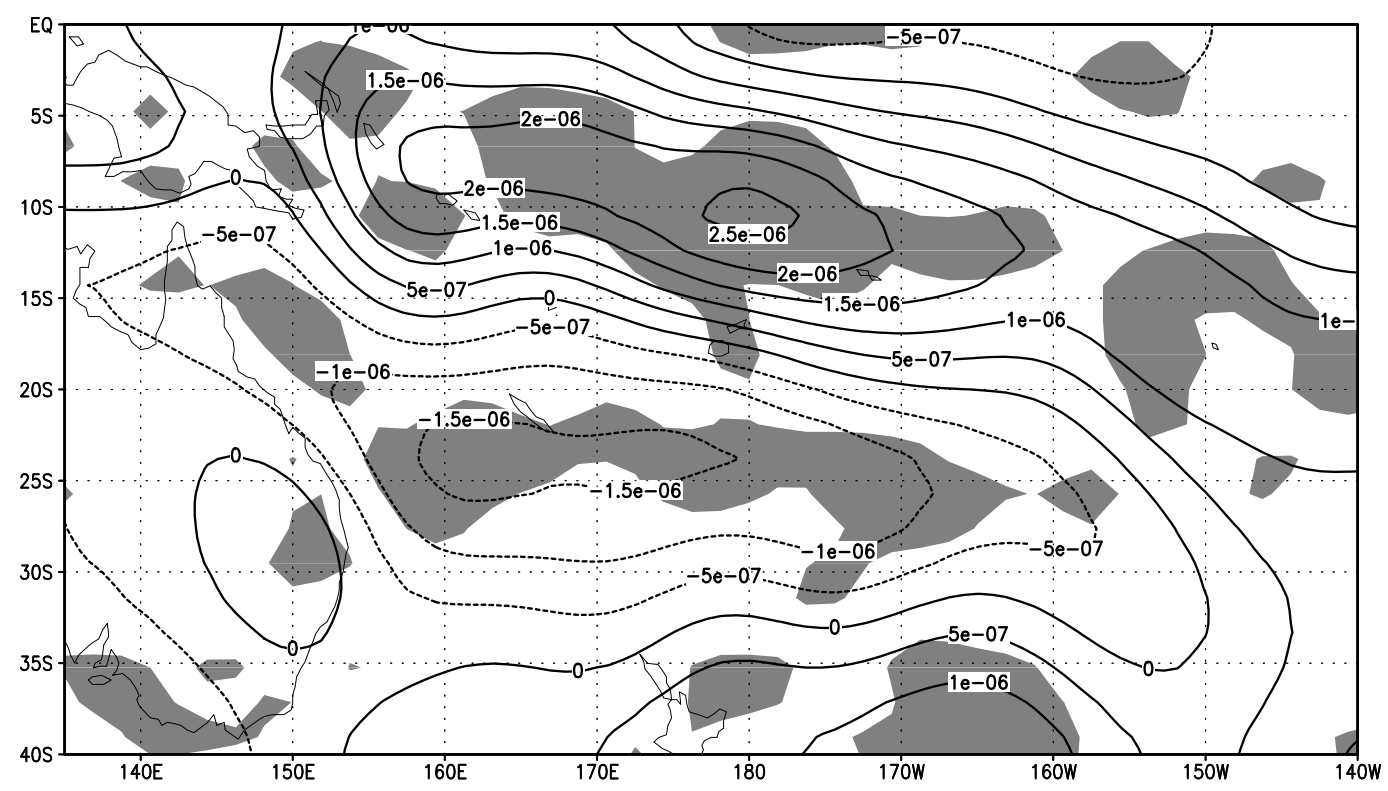

Fig. 12. Vorticity anomalies at 0.995 sigma level $\left(\mathrm{s}^{-1}\right)$ over the South Pacific Ocean for (a) El Niño and (b) La Niña episodes. The shades indicate areas where the statistical test is significant at the $95 \%$ level.

to the equator while cyclonic vorticity anomalies located between latitudes around $15-25^{\circ} \mathrm{S}$ contribute to increase in TC activity in the Australian region.

Relatively low vertical wind shear observed in the central equatorial and tropical areas of the basin also enhances TC activity in the central and eastern part of the basin in El Niño episodes. During La Niña episodes, low vertical wind shear west of $180^{\circ}$ enhances cyclogenesis in areas closer to Australia.

This study demonstrates that over the whole South Indian Ocean basin, the changes in geographical distribution of relative humidity and vorticity are primary contributors to the 
variations in TC genesis related to the ENSO phenomenon. Positive anomalies of SSTs observed during La Niña seasons in the eastern part of the basin also contribute to enhanced cyclogenesis near the Western Australia.

In the Pacific, large-scale environmental changes associated with the ENSO (i.e. changes in near-equatorial SSTs and the Walker Circulation) significantly affect TC genesis. Changes in geographical distribution of relative humidity and vorticity are primary factors influencing tropical cyclogenesis over the entire South Pacific, with changes in SSTs and vertical wind shear additionally favouring enhanced TC activity in the eastern (western) part of the basin during El Niño (La Niña) years.

These finding are in agreement with general conclusions of Camargo et al. (2007) that mid-tropospheric relative humidity and vertical wind shear are important contributors to variation in tropical cyclogenesis in the basins of the Southern Hemisphere; however our results also highlight the key role of vorticity and additional contribution of changes in SSTs in the South Indian and the South Pacific Oceans.

This study confirms that during El Niño events TC activity in the South Pacific is displaced away from the Australian coast further eastward (Gray, 1988; Basher and Zheng, 1995) and it reports that relative humidity and vorticity are the key factors of the South Pacific TC environment.

In summary, using the data from recently developed TC archive for the Southern Hemisphere, changes in tropical cyclogenesis over the South Indian and South Pacific Oceans related to changes in the ENSO phases have been investigated in this study. Significant variations in geographical distribution of areas of enhanced TC genesis have been identified. To explain these changes, large-scale environmental factors which influence TC genesis and development such as sea surface temperature, relative humidity in midtroposphere, vertical wind shear and lower tropospheric vorticity have been examined. In the South Indian Ocean, reduction of TC genesis in the western part of the basin and its increase in the eastern part as well as displacement of the area favourable for TC genesis further away from the equator during La Niña events compared to El Niño events can be explained by changes in geographical distribution of relative humidity and vorticity across the basin as primary contributors; positive anomalies of SSTs observed during La Niña seasons in the eastern part of the basin also contribute to enhanced cyclogenesis near the Western Australia. In the South Pacific Ocean, changes in geographical distribution of relative humidity and vorticity appear to be the key largescale environmental factors responsible for enhanced TC genesis in the eastern (western) part of the basin as well as for the northeast (southwest) shift of points of cyclogenesis during El Niño (La Niña) events, with vertical wind shear and SSTs as additional contributing environmental factors.
Acknowledgements. This study was supported by the Australian Greenhouse Office and the Laboratory of the Atmosphere and $\mathrm{Cy}$ clones at the University of La Réunion and Météo-France. We thank the Physical Sciences Division (PSD) of the Earth System Research Laboratory, NOAA for the NCEP re-analysis dataset (http: //www.cdc.noaa.gov).

Topical Editor F. D'Andrea thanks two anonymous referees for their help in evaluating this paper.

\section{References}

Basher, R. E. and Zheng, X.: Tropical cyclones in the Southwest Pacific: spatial patterns and relationships to Southern Oscillation and sea surface temperature, J. Climate, 8, 1249-1260, 1995.

Bister, M. and Emanuel, K. A.: Dissipative heating and hurricane intensity, Meteor. Atmos. Phys., 52, 233-240, 1998.

Camargo, S. J., Emanuel, K. A., and Sobel, A. H.: Use of a genesis potential index to diagnose ENSO effects of tropical cyclone genesis, J. Climate, 20, 4819-4834, doi:10.1175/JCLI4282.1, 2007.

Chen, W. Y.: Assessment of Southern Oscillation sea-level pressure indices, Mon. Weather Rev., 110, 800-807, 1982.

Chan, J. C. L.: Tropical cyclones activity over the western North Pacific associated with El Niño and La Niña events, J. Climate, 13, 2960-2972, 2000.

Chu, P.-S.: ENSO and tropical cyclone activity. Hurricanes and Typhoons : Past, Present and Potential, R.J. Murnane and K.B. Liu ed., Columbia University Press, New-York, 297-332, 2004.

Climate Prediction Center web page: http://www.cpc.ncep.noaa. gov/products/analysismonitoring/ensostuff/ensoyears.shtml, last access: April 2009.

DeMaria, M.: The effect of vertical shear on tropical cyclone intensity change, J. Atmos. Sci., 53, 2076-2087, 1996.

Evans, J. L. and Allen, R. J.: El Niño/Southern Oscillation modification to the structure of the monsoon and tropical activity in the Australian region, Int. J. Climatol., 12, 611-623, 1992.

Gray, W. M.: Global view of the origin of tropical disturbances and storms, Mon Weather Rev., 96, 669-700, 1968.

Gray, W. M.: Hurricanes: their formation, structure and likely role in the tropical circulation, in: Meteorology over the tropical oceans, edited by: Shaw, D. B., Roy. Meteor. Soc., 155-218, 1979.

Gray, W. M.: Atlantic seasonal hurricane frequency. Part I: El Niño and $30 \mathrm{mb}$ quasi-biennial oscillation influences, Mon. Weather Rev., 112, 1649-1668, 1984.

Gray, W. M.: Environmental influences on tropical cyclones, Aust. Meteor. Mag., 36, 127-139, 1988.

Hastings, P. A.: Southern Oscillation influences on tropical cyclone activity in the Australian/South-west Pacific region, Int. J. Climatol., 10, 291-298, 1990.

Kalnay, E., Kanamitsu, M., Kistler, R., Collins, W., Deaven, D., Gandin, L., Iredell, M., Saha, S., White, G., Woollen, J., Zhu, Y., Leetmaa, A., Reynolds, B., Chelliah, M., Ebisuzaki, W., Higgins, W., Janowiak, J., Mo, K. C., Ropelewski, C., Wang, J., Jenne, R., and Joseph, D.: The NCEP/NCAR 40-Year Reanalysis Project, B. Am. Meteorol. Soc., 77, 437-472, 1996.

Kuleshov, Y., Qi, L., Fawcett, R., and Jones, D.: On tropical cyclone activity in the Southern Hemisphere: Trends and the ENSO connection, Geophys. Res. Lett., 35, L14S08, doi:10.1029/2007GL032983, 2008. 
Kuleshov, Y., Qi, L., Fawcett, R., and Jones, D.: Improving preparedness to natural hazards: Tropical cyclone prediction for the Southern Hemisphere, Adv. Geosci., 12 Ocean Science, edited by: Gan, J., World Scientific Publishing, Singapore, 127-143, 2009.

Maloney, E. D. and Hartmann, D. L.: Modulation of Eastern North Pacific Hurricanes by the Madden-Julian Oscillation, J. Climate, 13, 1451-1460, 2000.

Merrill, R. T.: Environmental influences on hurricane intensification, J. Atmos. Sci., 45, 1678-1687, 1988.

Nicholls, N.: The Southern Oscillation, sea-surface-temperature, and interannual fluctuations in Australian tropical cyclone activity, J. Climatol., 4, 661-670, 1984.

Nicholls, N., Landsea, C. W., and Gill, J.: Recent trends in Australian region tropical cyclone activity, Meteor. Atmos. Phys., 65, 197-205, 1998.

Physical Sciences Division of NOAA web page: www.cdc.noaa. gov, last access: April 2009.
Ropelewski, C. F. and Jones, P. D.: An Extension of the TahitiDarwin Southern Oscillation Index, Mon. Weather Rev., 115(9), 2161-2165, 1987.

Saunders, M. A., Chandler, R. E., Merchant, C. J., and Roberts, F. P.: Atlantic hurricanes and NW Pacific typhoons: ENSO spatial impacts on occurrence and landfall, Geophys. Res. Lett., 27, 1147-1150, 2000.

Trenberth, K. E.: The Definition of El Niño, B. Am. Meteorol. Soc., 78(12), 2771-2777, 1997.

Troup, A. J.: The Southern Oscillation, Q. J. Roy. Meteorol. Soc., 91, 490-506, 1965.

Wolter, K.: The Southern Oscillation in surface circulation and climate over the tropical Atlantic, Eastern Pacific, and Indian Oceans as captured by cluster analysis, J. Climate Appl. Meteor., 26, 540-558, 1987.

Zehr, R. M.: Environmental vertical wind shear with Hurricane Bertha (1996), Wea. Forecasting, 18, 345-356, 2003. 